УДК 94(47).031

DOI: $10.22378 / 2313-6197.2018-6-1.18-40$

\title{
THE RISE OF URBAN CENTERS IN THE GOLDEN HORDE AND THE CITY OF ÜKEK
}

\author{
Uli Schamiloglu ${ }^{1,2}$ \\ ${ }^{1}$ Nazarbayev University \\ Astana, Kazakhstan \\ uli.schamiloglu@nu.edu.kz \\ ${ }^{2}$ University of Wisconsin-Madison \\ Madison, USA \\ uschamil@wisc.edu
}

Research objectives and materials: This essay discusses the rise of cities in the territories of the Golden Horde. It contextualizes the information found in European travelers such as Marco Polo and William of Rubruck to examine the transition from a nomadic economy to a sedentary economy. Arabic sources such as Abū l-Fidā allow a survey of the location of the major urban centers while Ibn Battūta allows a deeper understanding of the composition of cities. While Ukek started as an urban center situated at the northern limit of the annual nomadic migration route and midway between the capital city Saray in the south and the city of Bulgar in the north, the essay argues that it is likely that it later gained in importance as a center for grain production as the result of climate change. It also attempts to understand the origin and meaning of the name Ukek, for the etymology of which it offers a detailed examination of medieval and modern data.

Results and novelty of the research: The essay proposes that the name Ukek actually relays information about the geological formation of the site on which it is built. While most scholars have understood the original meaning of 'box' to represent fortifications built on the city wall, the author argues that the name refers rather to the boxlike hollow shape of the formation, which offered both shelter and an elevated location which would be both visible to travelers as well as a shape easily recognized by travelers coming from thousands of kilometers from the southeast, where there were several other such formations carrying the same name.

Keywords: Ukek, nomadism, camps, proto-cities, urban centers, Saray, geological feature, grain production, Turkic etymology, Mongolian etymology

For citation: Schamiloglu U. The Rise of Urban Centers in the Golden Horde and the City of Ükek. Zolotoordynskoe obozrenie=Golden Horde Review. 2018. Vol. 6, no. 1, pp. 18-40. DOI: 10.22378/2313-6197.2018-6-1.18-40

\section{Introduction}

In this contribution devoted to several aspects of the history of the Golden Horde city Ükek, I would first like to offer a brief overview of the rise of urban centers in the Golden Horde. I would then like to use this as the context for trying to evaluate the development and role of Ükek as a city in the Golden Horde. I will also discuss the etymology of the name Ükek and offer the most likely solution for a correct etymology, including what it might mean relative to the actual site of the medieval settlement. Finally I would like to offer a few concluding thoughts on 
what factors might have led to the transformation of Ükek into a major urban center during the period of the Golden Horde $\left(13^{\text {th }}-14^{\text {th }}\right.$ centuries).

We may begin by observing that the majority of the population of the Golden Horde, including its ruling élite, led a nomadic lifestyle in the mid- $13^{\text {th }}$ century. By the $14^{\text {th }}$ century, however, the ruling élite had established itself for part or all of the year in fixed sedentary centers. There have been relatively few attempts to offer an overview of urban life in the Golden Horde ${ }^{1}$. Today we can view the Golden Horde as a state in which pre-existing urban centers flourished and new ones were created on sites probably not inhabited by sedentarists at the time of the Mongol invasions. Viewed from a distance of well over seven centuries, the destruction of urban centers during the intial conquests was connected with destruction of local centers of political, military, and economic power. These centers would have resisted the conquest of western Eurasia by the Mongol World Empire. Their destruction was, however, an anomalous fact compared to the well-documented expansion in urban life in the territories of the patrimony of Batu over the course of the $13^{\text {th }}-14^{\text {th }}$ centuries. This is one of the most important aspects of the urban history of the Golden Horde for which data are now available.

As I have described elsewhere, another important aspect is that these same urban centers served as a home for a cosmopolitan Islamic civilization [see my: 49; 51]. Although the Golden Horde was a model of religious tolerance in the $13^{\text {th }}$ century, the conversion of the ruling élite and the integration of the Golden Horde into the Islamic world over the course of the $13^{\text {th }}-14^{\text {th }}$ centuries necessarily led to the introduction of Islamic religious knowledge, art and architectural forms, epigraphical languages, religious and belletristic literary forms, and even Islamic science. This picture would not last, however, once the waves of bubonic plague known as the Black Death struck the territories of the Golden Horde beginning in the middle of the $14^{\text {th }}$ century [on the Black Death in the Golden Horde see most recently my: 48]. The demographic collapse in this period necessarily meant that the urban centers of the Golden Horde would would also rapidly decline and suffer from the political and military unrest of this "time of trouble".

\section{The Nomadic Background: Migrations and Proto-Cities}

The development of towns and the transition of the Golden Horde's ruling élite and state apparatus to an urbanized way of life did not come about through an overnight transformation (nor does this article take into consideration earlier cities in eastern Eurasia such as Qaraqorum). Rather, the process should be considered a gradual one spread over many decades, and one may even ask whether the process was ever fully completed. The sources for the Mongol World Empire in the mid- $13^{\text {th }}$ century already describe the ruler's camp as mobile centers of population and economic activity. One might almost consider these camps, which followed the seasonal migrations of the élite and the rest of the population, as proto-cities forming a model for some of the fixed urban centers, at least for Saray if not for the later New Saray. The Western travelers John of Plano Carpini and William of Rubruck, who followed the normal routes taken by merchants during the reign of Batu, visited Batu's mobile camp, not the new capital city that William of Rubruck

${ }^{1}$ In this regard the works of Fedorov-Davydov stand out as an exception, see for example: $[17 ; 18 ; 19]$ and more recently Kramarovskiy [25]. It is worth noting that even the 3rd volume of Istoriya Tatar offers only a limited treatment of urban life in the Golden Horde. 
said had just been established [59, p. 207]. Although there is a reference in an Armenian source to Batu Khan's enormous "tent city", if we may call it that, on the Volga (Etil) River, it is not clear whether this is possibly a reference to the newly-established capital city of Saray or just to his mobile camp [24, p. 217-218; 23, p. 292-293]. Whether this source is describing Saray or a mobile proto-city, the reference may be compared with 'Umarî's more detailed description of the phenomenon of tent cities in the Il-khanate, including how these mobile cities were followed by important markets [57, p. Ar. 87/149 and Ar. 99/157].

It is not possible to ascertain how much Batu used Saray, if at all. What is clear from William of Rubruck's account is that Batu Khan continued to nomadize despite the establishment of a fixed urban center [59, p. 126 and p. 207-210]. If the reign of Batu marked the first step in the end of the ruling élite's exclusively nomadic existence, the reign of his successor Berke should be seen as marking the beginning of a transition to a sedentary way of life. According to the report of Marco Polo, his father Niccolò and his uncle Maffeo traveled in 1260 from Sudaq to the court of Berke, who according to this source was living at that time in Bulğar (Bolgara) and Saray [30, p. 34]. When viewed from the perspective of the transition from mobile camps to fixed cities, this report raises the question of whether the ruling élite continued to follow a pattern of seasonal migrations after the establishment of a major fixed sedentary center. If Marco Polo's report is accurate, around 1260 Berke was treating Bulğar in the north and the recently-established Saray of Batu in the south as his two residences. (It seems less likely that the later New Saray of Berke is meant here.) Although Bulğar was north of the limit of traditional north-south pastoralism along the Volga River, it clearly could have served as Berke's seat of government for part of the year, in all likelihood during the summer; in such a case Saray would have served as his winter capital. Bulğar was probably attractive to Berke, an early convert to Islam, because of its role as an important center of Islamic religious learning as well.

It is certain that by the $14^{\text {th }}$ century the khan and his court would spend the winter in the south in one of the capitals called Saray, since Ibn Battuntạa visited the court of Özbek Khan in Saray during the winter ${ }^{2}$. Yet, it is not clear whether the khans of the Golden Horde ever abandoned the seasonal search for more favorable climatic conditions, nor should we expect that they ever did, if we may judge by patterns of human behavior even at the beginning of the $21^{\text {st }}$ century. There is evidence to suggest that the khans of the Golden Horde continued to travel north in the summer to the mountains (rather than to Bulğar, as described by Marco Polo), but it is not clear whether this report refers to the time of the compilation of this source in the mid- $14^{\text {th }}$ century or to an earlier period ${ }^{3}$. We also know from Ibn Bațtutta's first encounter with Özbek Khan that the khan and his entourage were traveling in the form of a mobile camp at the time, which indicates that in all likelihood even Özbek Khan never followed a completely sedentary way of life [22, ii, p. $481 \mathrm{ff}$.].

${ }^{2}$ For the translator's analysis of the chronology of Ibn Battūtạa's itinerary, see: [22, ii, p. 531]

3 According to 'Umarī, the khans went to the $A R Q$ Tağ mountains during the summer, which could possibly be a reference to the Ural Mountains [57, p. Ar. 83/147]. The Il-khanid rulers also continued to practice seasonal migrations, as seen in 'Umarī [57, p. Ar. 87/149]. 


\section{The Rise of Cities as Nodes of Commerce}

The most important question, however, is what factors might have led to to the establishment of fixed urban centers, indeed capital cities, in areas formerly inhabited by nomads. Certainly the evidence just cited suggests that they may not have been intended solely to serve the purpose of year-round residences for the khan. Rather, we should consider Le Goff's observation that towns served as nodes in the network of long-distance trade [26, p. 78]. Indeed, I would argue that the centrality of trade to the economy of the Golden Horde was the most critical factor in the establishment of new towns and even cities [on the commerce of the Golden Horde see my: 50]. Before proceeding with this argument, however, I would simply like to suggest other factors which one might also consider. For example, there is too little data to ascertain whether there was a growing population in the Golden Horde and in its subject states through the middle of the $14^{\text {th }}$ century which might also have contributed to a process of sedentarization and urbanization. Such a demographic trend has been described for much of Western and Eastern Europe in the same period, but it has not been discussed in the case of western Eurasia, see the discussion in: [26, p. 245; and also 9, p. 57-65].

Already the earlier mobile proto-cities served a commercial function, as is clear from the accounts of the European travelers of the $13^{\text {th }}$ century, who did not visit Saray in the steppe zone. Fixed settlements, towns, and even cities would not have developed in the steppe zone, let alone flourished, without the fulfillment of several conditions. One of these was the security afforded trade routes in the steppe zone by a strong state-sponsored security apparatus, in the case of the Golden Horde the so-called "Pax Mongolica". One of the results of this strong security, which meant protection from possible predatory raids by highly-mobile nomadic forces, was that centers of sedentary habitation could exist successfully in the steppe zone traditionally inhabited by nomads. Immediately prior to the Mongol conquests Kiev and the commercial centers of the Volga-Kama confluence, the Crimea, and Xwarezm had relied on cooperation with the nomadic Kipchak Turks (including the Polovtsians) to provide security for trade routes and for the city itself. Such security was not intended for the well-being of the citizens of the state. Rather, it was necessary for the promotion and success of markets and international commerce over the entire steppe zone, which would, of course, result in increased tax revenues for the sedentary and nomadic states concerned.

In contrast to the protection afforded these centers by nomadic Kipchak Turks, the Golden Horde combined both the function of state security for international commerce and the function of sponsorship of marketplaces under a single state apparatus. Etil must have served the same function centuries earlier under the security offered by the Khazar state. The promotion of commercial activity also required the development of a commercial infrastructure in the steppe zone, including marketplaces, accommodations and warehouses for merchants, and the toll barriers from which the ruling élite would derive a steadily increasing income. While the original mobile proto-cities could offer only limited services to merchants, the steady increase in commercial activity already in the mid- $13^{\text {th }}$ century necessitated the establishment of large fixed commercial centers that could be reliably located by travelers year-round already by the end of Batu's reign, i.e. before the even more dramatic increase in commercial relations with the Italian maritime republics. 
It is no coincidence that the capital cities of Saray and later New Saray were strategically located along the crossroads of international commerce passing through the territories of the Golden Horde and served more or less the function of international commercial centers. Many other towns also emerged along trade routes to facilitate commercial activity by serving as entrepôts and marketplaces. Many smaller settlements were created along the routes of trade and communication for other reasons such as manning river crossing stations and transportation stations for changing horses (including for the couriers of the imperial messenger system), toll barriers, and bases from which trade expeditions could be mounted to outlying areas such as the sources of furs in the distant forests of the north.

The urban centers in the steppe zone would have served no purpose in the absence of extensive commercial activity, nor would it have made any sense for the state or for individuals to engage in the costly task of building an urban center and sponsoring monumental architecture in the absence of a significant source of revenue to support such building activity. It is not clear, however, whether there was a system of caravansarais in the steppe regions of western Eurasia; Ibn Batṭutta does refer to "stations" between cities [22, ii, p. 475]' The presence of urban centers in the steppe zone such as Etil in the Khazar period and the two Sarays in the Mongol period bespeaks a significant volume of international trade, most notably through the Black Sea, and the absence of such centers in certain periods such as during the Kievan period may indicate a significantly lower level of commercial activity in these same territories.

We do not know what portion of the cost of developing these sites - no doubt a huge investment - was borne by the Golden Horde state. It is possible that individual commercial buildings or larger complexes were paid for by individual merchants or trading associations. It is clear in certain cases, however, that specific examples of monumental architecture were sponsored by wealthy members of the ruling élite, including the khan and his tribal leaders. In addition to the palaces of the khan and similar buildings, there were mosques and other religious structures endowed by the khan and other members of the ruling élite and their wives, not to mention baths and other kinds of structures as well. Another phenomenon necessarily accompanying the emergence of fixed urban centers was the creation of a far higher degree of economic specialization among the labor force than under a subsistence-level pastoral nomadic economy. Earlier, artisans were relocated in towns and settlements along the trade routes to produce luxury goods, and other segments of the population, including Slavs, were relocated to raise food and provide other services for the state. By the $14^{\text {th }}$ century, additional jobs and services were no doubt required to maintain urban centers with a permanent ruling class, security apparatus, artisans, commercial infrastructure, and religious-learned class. The new socio-economic groups which formed in the cities, towns, and settlements which came into existence as a direct or indirect result of the policies of the Golden Horde state came to represent an integral part of its population by the mid- $14^{\text {th }}$ century. 


\section{The Major Urban Centers of the Golden Horde}

Turning to the urban centers themselves, the great traveler Ibn Batțūta, whose itinerary included Kaffa, Qırım, Azaq, Māçar, Saray, Sarayçuq, and Xwarezm, is one of the unique sources allowing us to see the towns of the Golden Horde, and especially its great cities, as vibrant and complex cosmopolitan centers. Other written sources offer far less information. 'Umarī cites a report including references to Xwarezm, Sı̆̆ınaq, Sawran, Barkent, Cend, Saray, Macar, Azaq, Aqça Kerman, Kaffa, Sudaq, Saqsin, Ükek, and Bulğar as cities of the Golden Horde [57, p. Ar. $75 / 142]$. Some of these were sites of traditional sedentary settlement representing continuity of habitation in the southern and northern zones, while others were new urban centers established in the steppe zone during the $13^{\text {th }}-14^{\text {th }}$ centuries on sites that were previously uninhabited. Although many of them predate the Mongol campaigns, the traditional urban centers of both Xwarezm and the Crimean peninsula became centers of state administration rather late, if we are to judge by their role as mint sites. As can be seen from the maps provided by Yegorov, the archeological record reveals many additional sites whose names are not even known from the medieval sources [62].

The traditional urban centers of the south were quite different in character from the cities established in the forest-steppe zone in the centuries preceding the Mongol campaigns and especially from the new cities established in the steppe zone during the $13^{\text {th }}-14^{\text {th }}$ centuries. Most centers in both the Crimea and in Xwarezm were communities that had existed for centuries or even millenia. Even Kaffa, developed through the activity of the Italian maritime republics, was in the same location as the ancient Theodosia.

We must, however, look to the urban centers established in the steppe zone by the khans of the Golden Horde to serve as their capitals to understand the quintessential creations of the Golden Horde. Only the two capital cities of Saray can give us clear insight into what the rulers of the Golden Horde considered to be a city. What is left of the first of these capital cities, commonly known as Saray or Saray Batu (also known as Saray al-mahrūsa), is associated by archeologists with the modern site $118 \mathrm{~km}$ north of Astrakhan known as Selitrennoye (near Axtubinsk) along the Axtuba River, a branch of the lower Volga River. The second city, New Saray (or Saray al-cad'd, from Arabic cadīd 'new'), also commonly known as Saray Berke, is associated by archeologists with the modern site $360 \mathrm{~km}$ north of Astrakhan known as Tsarev, which is near the great bend of the river.

Let us consider for a moment why the capital of the Golden Horde was such a remarkable achievement for that time and place. Ibn Battututa, who traveled to Saray Berke following his visits to Azaq and Maçar, has provided us with our only vivid description of life in this city. He considered Saray "one of the finest of cities, of boundless size, choked with the throng of its inhabitants, and possessing good bazaars and broad streets". It took him a whole day to ride its length and return home, and he walked its breadth and back in half a day through a continuous line of houses among which there were no ruins and no gardens. Özbek Khan had a palace in this city, and the inhabitants of the city included Mongols, As (Alans), Kipchaks, Cherkes, Russians, and Greeks $(R \bar{u} m)$. Each group lived in its own separate quarter with its own bazaars. Merchants and visitors from Iraq, Egypt, Syria, and elsewhere lived in a separate quarter surrounded by a wall for the protection of the 
properties of the merchants [22, ii, p. 515-517]. We can see from this description alone that Saray Berke was truly a cosmopolitan center.

Unfortunately, very little else about the study of the capital cities of the Golden Horde is as coherent and straightforward as Ibn Batțūta's elegant description. Unfortunately, some of the sources do not even clarify whether they are referring to the original Saray (Saray Batu) or the later New Saray (Saray Berke), nor is it ever entirely certain that the author of a given source is even aware that there are two different Sarays. This has also led to a certain amount of confusion among modern scholars. Certain details are no doubt true of both capitals, such as Abū 1-Fidā's comment that Saray (in this case Abū 1-Fidā is referring to the Saray founded by Batu) is frequented by merchants and is the site of a great trade in Turkic slaves [1, p. 322-323]. (Since Abū 1-Fidā also draws on sources from the pre-Mongol period, his account often introduces additional complications.) In other instances it would be interesting to know which Saray is meant, as in the case of 'Umarī's description of a palace with a gold crescent moon which served as the winter residence of the khan and towers serving as residences for the emirs [57, p. Ar. 81/146], compare Ibn Battututa's description. For example, if we could be certain that this information refers, in fact, to the more northern Saray Berke, it would add further evidence substantiate the view that the khan was no longer wintering with the flocks along the lower Volga. Following this background survey of the rise of urban centers in the Golden Horde, let us now turn to a consideration of Ükek as a Golden Horde city.

\section{A Brief Overview of Ükek in the Written Sources}

Today the old city of Uvek - site of the medieval city of Ükek - is a small village about $10 \mathrm{~km}$ south of the city of Saratov ${ }^{4}$. By the $14^{\text {th }}$ century, however, it had become one of the most important cities of the Golden Horde, situated approximately halfway between the the Golden Horde capital of Saray in the south and the city of Bulğar in the north. The city is mentioned by Marco Polo under the year 1260, when the Polo brothers traveled from the court of Berke to Ükek (Ucaca) on their way to Bukhara [30, p. 35].

The name Ükek also appears mentioned in the Islamic sources. As already noted above, 'Umarī mentions it as one of the cities of the Horde [57, p. Ar. 75/142]. Vașsāf describes that the lands ruled by Chinggis Khan's oldest son Jochi are "Saqsin, Qipçaq, Xwarezm, Bulğar, Qirim, and Ukak as far as Russia" [58, p. 86]. Timurid chroniclers also mention Ükek in connection with the the battles in the mid-1390s (ca. 1395) between Timur and Toqtamış [42, p. 121; 53, p. 178 and 185]. On the other hand, some other references in the sources are more problematic: the so-called "Iskandar Anonymous" lists Ükek ( $\bar{U} k a k)$ among the lands of the "Blue Horde" rather than the "White Horde" (the correct name for the western part of the "Golden Horde", which is one of the reasons why I have serious

${ }^{4}$ I am aware that many local scholars in Saratov have published detailed works on the history of Ükek and Saratov, but it is not possible for me to give a thorough review of recent developments in local scholarship in Saratov here. For a detailed survey I refer the reader to the work of a colleague in Saratov who kindly shared her work with me, see: [10]. 
misgivings about this source) $[3 \text {, Pers. p. } 232 / \text { p. } 127]^{5}$. The same error is repeated by Gaffari [20, p. 211].

More details are offered by Abū 1-Fidā, who describes Ükek (al-Ukak) as a small city of the seventh clime, situated (by induction) at 78 degrees longitude and 49 degrees 55 minutes latitude in the country of Saray [1, p. 323-324] $]^{6}$. It is built along the west bank of the Volga halfway between Saray and Bulğar (Bular) meaning about 15 days journey in either direction to reach one city or the other. According to this source, the "horde" of the Tatar prince of the country of Berke travels as far north as Ükek but does not go beyond this point [1,'p. 323-324]. We may recall that the northern point of nomadization along the Volga by Batu's orda is the same spot for which William of Rubruck describes a part-Ruthenian, part-Saracen village recently established by the Tatars to serve as a river crossing [59, p. 126]. At the conference devoted to the history of Uvek held on June 4-6, 2015 in Saratov, many scholars asserted that Ükek was the site of a river crossing cited by William of Rubruck. While William of Rubruck does not state the name of the place explicitly, it indeed appears justifiable to consider Ükek as the site of the northern river crossing.

Drawing on the coins described by Yanina, we know that Ükek served as a mint site under the reign of Toqta (r. 1290-1313) [63, p. 169-175]. Even though it served as a mint site only later, clearly it apears the urban center had been established much earlier, certainly by the time of the visits of William of Rubruck (1253) and the Polos (1260). By the time Ibn Battūṭa visited Ükek (Ukak) in 1332, the great traveler was able to describe it as "a city of middling size, with fine buildings and abundant commodities, and extremely cold". He located it ten nights' march to "the sultan's capital" Saray and one day's march from the mountains of the Christian Rūs [22, ii, p. 498-499 (cf. n. 306 citing Yule)]. (Could the difference in the number of days given by Abū l-Fidā versus the number of days given by Ibn Battututa reflect the different locations of the two distinct Sarays, the earlier one more distant from Ükek and the later one closer to it?) Since Ibn Battututa considers Ükek to have been of "medium size", one may venture a guess that its population was perhaps in the range of roughly $10,000-25,000^{7}$. Of course, as Leonard Nedashkovsky shows, there were many other settlements in the region surrounding Ükek and other cities of the Golden Horde, see: [39; 40; 41]. As I will suggest below, that must also have represented a significant population.

\section{5. Ükek as a Geological Feature?}

In the interest of comprehensibility I will turn to an extended discussion of the etymology of the name $\ddot{U} k e k$ only at the end of this paper rather than in the middle of it. For a discussion of Ükek as potentially referring to a geological feature, however, it is important to be aware for our purposes here that the word can mean 'a box' or by extension (?) 'a 'wall tower', see: [13, p. 105]. For an extended discussion of this word in Turkic and Mongolian languages, I refer to the reader to the final section at the end of this paper.

\footnotetext{
${ }^{5}$ The full work has been published as [38].

${ }^{6}$ Today we would say that Uvek, Russian Federation is located at 45.966542 degrees E longitude and 51.427416 degrees $\mathrm{N}$ latitude.

${ }^{7}$ I discuss the basis for estimating the size of the population of the cities of the Golden Horde in my: [52, chapter 8].
} 
Menges has noted that earlier maps point out the existence of a mountain range called Ükek-Daba 'Walltower pass range' (?) in the Khangay Mountains, Mongolia located at 47 degrees $\mathrm{N}$ latitude and 100.2 degrees $\mathrm{E}$ longitude [35, p. 30]. I could not confirm this toponym or find any images of this location (except through Google Earth, see image 1 in the Appendix). With modern technologies and internet search engines, however, it is possible to cast one's net wider to find places incorporating $\ddot{u} k e k \sim \ddot{u} k o ̈ k$ in toponyms and easily find images of these places. I would like to offer two additional examples of this.

In one area near Naryn, Kyrgyzstan we find the Ükek Suusu river, Köl-Ükök lake, and the Pereval Ukek or Ükök Pass (located at 42.0182 degrees N latitude and 75.9756 degrees E longitude, average elevation 3,941 meters) in the Gory Ukek mountains. A second area would be the Ükök Plateau in the Altay Republic, more recently the site of the discovery of the "Princess of Ükök", a well-preserved female mummy from the $5^{\text {th }}$ century BCE, see: [54]. What is striking about all of the maps and photos I have been able to gather concerning these geological features is that they all seem to share the feature of being surrounded completely by a range of mountains, or sometimes on two sides (in the case of a river or mountain pass). Could it be that the mountains provide a protected enclosure (on however large a scale), similar to that offered by a box or a chest (as in the definition offered by Kaşgari cited by Clauson or found in modern Turkic and especially Mongolian languages)? Is it even necessary to be enclosed on all sides, or is it enough to have the high wall of a geological feature protecting the site on just one side?

The reason I pose this question is because it seems to me that the physical site of Uvek (the former Ükek) has geological features which are strikingly similar to the images I have found for Ükök Pass, Köl-Ükök lake, and Ükek Suusu river in Naryn, Kyrgyzstan and the Ükök Plateau in the Altay Republic, Russian Federation. (It is also similar to many images I have found for the Khangay Mountains, except I have not found any images for the precise location cited by Menges.) When looks at those images, one may ask whether the city of Ükek was called that because of its man-made walls (which it may well have had), or the towers built on the man-made walls (which it may have had as well), or whether it was chosen as a site whose geological characteristics would be immediately recognizable to any traveler coming from far off eastern regions of the Mongol World Empire located in present-day Mongolia, Kyrgyzstan, and the Altay Republic of the Russian Federation? If the location was chosen because of its location at the northern limit of nomadism (and perhaps the security and vista it offered, too), is it possible that the name given to this place because it looked just like the other places known by the name Ükek 2,500-4,000 km away to the southeast?

\section{The Transformation of Ükek into a Major Urban Center}

To conclude the first portion of my paper, I would like to review what I consider to be some of the possible factors contributing to the fact that Ükek became an important urban center, incorporating the data offered above with some new theories as well. First of all, it is clear from William of Rubruck that this is the northern-most point of nomadization by Batu and Abū 1-Fidā makes the same statement for the prince ruling over the country of Berke (see above). Although it is likely that other groups were nomadizing further to the north, for the purpose of 
developing the infrastructure of a state, it made sense to choose the southern-most point (Saray) and the northern-most point (Ükek) of the territory regularly traveled by the herds and personnel of Batu Khan and his successors.

Second, the site of Ükek was a recognizable geological formation by whose very name travelers would immediately recognize the location when they saw it. The site was more easily defended, its elevation offered better visibility, and if fires were lit in the towers at night it could serve as a beacon to guide travelers and caravans to its location.

Third, the infrastructure of the state eventually demanded the establishment of fixed urban centers serving the administrative needs of the state, as markets, and as the site of predictable river crossings serving the needs of couriers, merchants, and other travelers. As such Ükek would have served as an important northern crossroad along the Volga River for the trade routes connecting other nodes of commerce to the north, southeast, the southwest, and other directions.

Fourth, as the major urban center halfway between Saray and Bulğar, it should have developed as a major center of Islamic civilization, too. Fragments of Islamic grave markers found in Uvek (which as far as I know remain unpublished) remind one of the Volga Bulğarian inscriptions found further to the north. One should expect that more evidence will emerge to support the notion not only that Ükek was a major center of Islamic civilization along the Volga River, but a city with Christian inhabitants as well, as evidenced by a Franciscan residence there, see: [45, p. 95 and 243].

Finally, it is not clear whether the region surrounding Ükek was a major center of grain cultivation in the mid- $13^{\text {th }}$ century or not. (Of course, today the region surrounding Saratov is well known as a major center of wheat production, which is symbolic for the region.) When did this region first become a center of wheat production? I have noted elsewhere that Venice and the other Italian maritime republics began to import wheat from the territories of the Golden Horde in the $13^{\text {th }}$ century, see my: [50]. As I argue elsewhere, however, the 1280 s also marks the beginning of a climatic shift in the territories of the Golden Horde, see my: [47]. It appears that regions further to the south ceased to experience the moister conditions required for grain production as precipitation shifted to the north. For this reason, it is possible that beginning in the 1280 s the countryside around Ükek may also have grown in importance as a site of wheat production for export to Italy. This would have led to an increase in number of settlements around Ükek (as studied by Nedashkovsky, see above), an increase in the population of agricultural workers in this region, and even further growth in the importance of Ükek as a major commercial center.

\section{The Etymology and Significance of the Name $\ddot{U} k e k$}

While it is not my goal to offer a complete study of the etymology of the name Ükek, a study of the history of Uvek in the medieval period should consider this matter, too. For this reason, I would like to reproduce some of the basic information from international scholarship on Turkic and Mongolian philology so that it should be readily available to scholars who are not necessarily Turkologists, Mongolists, or linguists, or may not be able to consult all of these works firsthand.

Karl Heinrich Menges [35] and Max Vasmer [16] (who taught at Saratov State University during the period of the Russian Civil War) discussed the etymology of 
Uvek, proposing a Turkic origin with parallel forms in Mongolian languages as well. According to Vasmer's etymological dictionary of the Russian language [16, iv, p. 144]:

Uvek - nazvaniya razvalin na pravom beregu Volgi, nizhe Saratova, tyurk. Ükäk; zdes' naxodilas' rezidentsiya starshego syna Chingis-xana; sm. Bartol'd u Markvarta, WA 43; Shpuler, Gold. Horde 284, 296 i dr. Russk. nazvanie vosxodit k sev.-zap.-tyurk. iz *Üväk iz *Ügäk ot ükäk (Maxmud Kashgarskiy) "yashchik, stennaya bashnya", mong. ukuk, uxuk; sm. Menges, ZfslPh 24, 30 i sl.

Thus, according to Vasmer, Uvek is the name of the ruins on the right bank of the Volga downstream from Saratov, referring to Bartol'd (as cited by Markwart) and Spuler. The former reference should actually be to Schaeder's critical foreword to the posthumous edition of Markwart's work, not to the main body of the work itself (which has a separate pagination). Schaeder's foreword itself is citing Marquart's monograph on the Qumans in which he cites Vașạāf's description (already cited above, see also: [58, p. 86]) of the lands ruled by Chinggis Khan's oldest son Jochi as Saqsin, Qipçaq, Xwarezm, Bulğar, Qirim, and Ukak as far as Russia [46, p. 43*; citing 31, p. 80]. While there is no citation of Bartol'd at the location cited by Vasmer, Bartol'd does mention Ükek in his famed "Twelve Lectures on the History of the Turks of Central Asia" and other works, see: [7, p. 710; 6, p. 136; 8, p. 401-402; 5, p. 517]. Vasmer also cites the brief references to "Ukek" in the text and notes to Spuler's history of the Golden Horde [citing 55, p. 210 n. 5, 265 n. 8, 284, 296, 315, 416 n. 2, 427, 431, 435, and 448 n. 9].

\subsection{Old Turkic Forms}

Following Menges, Vasmer derives the name from NW Turkic (i.e., Kipchak Turkic) * $\ddot{U} v a ̈ k$ from an earlier from * $\ddot{U} g a ̈ k$, which is from $\ddot{u} k a ̈ k$ (found in Mahmūd al-Kāşgàn̄'s Dīwān luğāt al-turk) with the meaning 'box, wall tower" ${ }^{8}$. For this great $11^{\text {th }}$ century medieval dictionary of the Turkic languages written in Arabic Menges cites Brockelmann [11, p. 235], who translates this word and the additional words derived from it as:

ükäk'1. Kasten, Kiste; 2. Mauerturm' I, 74, 14, 15.

ükäklik'Kistenholz' I, 135, 12.

ükäklig 'mit Mauertürmen versehn' I, 135, 13.

ükäklänmäk 'mit Mauertürmen versehn sein' I, 258, 1.

Atalay's translation of the Dīwān lugiàt al-turk offers translations of the definition of these words into Turkish as follows (omitting the Arabic script) [29, i, pp.

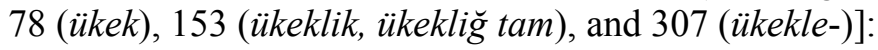

ükek : Tabut, sandık; Şehrin savaş için hazırlanmış olan etrafındaki burç.

${ }^{8}$ As noted above, I am not able to follow all the local scholars in Saratov who have written about the etymology of Uvek/Ükek, see for example: [10, p. 112] citing [32, p. 111]. 
ükeklik : Sandık yapılmak için ayrılan ağaç. Üzerinde burçlar bulunan kaleye "ükeklĭg tam" denir.

ükekledi : "ol tamı̆̆ ükekledi = o, kale üzerine burçlar yapti”. Herhangi bir şey için sandıklar yapmak ta böyledir; (ükekler - ükeklemek).

Dankoff and Kelley's translation of the Dīwān lug $\bar{a} t$ al-turk offers translations of the definition of these words into English as follows (omitting the transliteration of the Arabic script) [28, i, p. 116 (ükäk), 169 (ükäklig), 169 (ükäklik), and 249 (ükäklä:-)]:

ükäk 'Box (tābūt, șundīq).'

ükäklik 'Any piece of wood that is to be made into a box (șundīq).'

ükä:klig 'A wall on which there are towers ('alayhi burūj).'

ol tāmi ükäklä:di 'He put towers (burūj) on the city walls.' Also for putting boxes $(\operatorname{san} \bar{a} d \bar{\imath} q)$ on a thing. ükäklä:r ükäklä:mä:k.

Egeubay's translation of the Dīwān lug $\bar{a}$ t al-turk offers translations of the definition of these words into Kazakh as follows [33, i, p. 108 (ükek), 184 (ükek), and 361-362 (ükekle-)] (omitting the Arabic script):

ÜKEK: sandiq, tabit.

ÜKEK: qarauıl munara. Şaxar dualında, qorşau qabırğasında urıs üşin turğızılğan munaralar.

ÜKEKLİK: sandıq casauğa dayındağan ağaş. Töbesin kümbezdep şığarğan tamdı da "ükeklik tam : ükeklik tam" deydi.

ÜKEKLEDİ munaraladı. “Ol tamı̆̆ ükekledi : Ol tamığ ükekledi - Ol tamğa ükek (qarauıl munara) casadı. Bir närsege ükek qondırğanda osı söz qoldanıladı."

Auezova's translation of the Dīwān lugiāt al-turk offers translations of the definition of these words into Russian as follows [32, p. 111 ('ukak), 180 ('ukaklik), and 303 ('ukaklā-)] (omitting the Arabic script):

323 'ukak - 'yashchik, sunduk'.

324 'ukak - 'bashnya gorodskoy steny, osnashchennaya dlya boyevykh deystviy'.

877 'ukaklik - 'kusok dereva dlya izgotovleniya sunduka'. Stenu, na kotory stoyat bashni, nazyvayut 'ukāklik tām.

1608 ['ukaklā-] - ['ustanavlivat' (bashni, yashchiki, sunduki i t. p.)'] 'ul tāmig̀ 'ukaklādī 'on ustanovil bashni na gorodskoy stene'. Tak zhe govoryat i ob ustanovlenii yashchikov i sundukov. [Forma nastoyashchebudushchego vremeni i otglagol'noye imya:] 'ukaklār, 'ukaklāmāk. 


\subsection{A Turkic Etymology: Old and Middle Turkic Languages}

Sir Gerard Clauson offers a more complete etymology of this word in his classic etymological dictionary of Old Turkic [13, p. 105; see also 14, p. 623]:

ükek originally 'box' or the like; hence metaph[orically] 'a wall tower' on a city wall, Arabic burc, in certain contexts with the metaph[orical] meanings of that word. Survives only(?) in NE Tuv[an] ügek 'a small confined space, e.g. dog kennel, the interior of a covered cart, sentry box', and NC Kır[ğı] ükök 'a small box for carrying food'.

Clauson points out further that it survives in Kāşgarī's Dīwān lug $\bar{a} t$ al-turk $\left(11^{\text {th }}\right.$ century) as ükek al-tābūt wa'l-ṣundūq 'coffin, box'; ükek burc sūri'l-madīnati'l-mu 'adda li'l-harb 'a tower on a city wall built for military purposes' ${ }^{9}$. It also occurs in the Qutad $\breve{g} u$ bilig ( $11^{\text {th }}$ century) as on iki ükek 'the twelve signs of the zodiac' (Arabic burc) and in the phrase él(l)ig boynı kılça ükekçe başı 'a king with a neck as (thin as) a hair and a head as (thick as) a tower' (the understanding man does not trust him at all) [4, lines 138 and 2154]. According to Clauson, the line from the Qutad̆gu bilig is copied directly by Rabğuzi in his Qusas ül-enbiya' (early $14^{\text {th }}$ century), a work from Rıbat-i Oğuz in the territory of the Golden Horde ${ }^{10}$. Finally, Ibn Muhanna also has ü:ge:k which he glosses as al-burc (here) 'a sign of the zodiac', reproduced below from the editions by Melyoranskiy and Rifat (clearly the manuscript has a misspelling, with the letter lam instead of kaf) [34, Arabic p. 78; and 21, p. 183]:

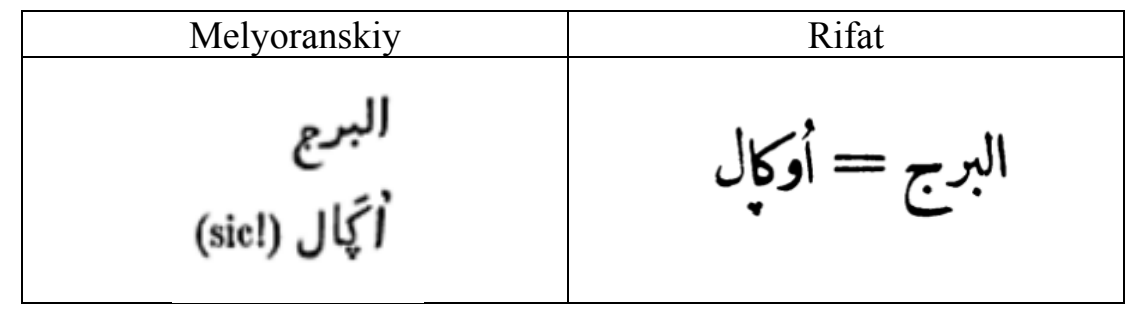

As Clauson notes, this form already shows the voicing of $-k->-g$ - (on the path to eventually becoming $-v$-, as noted above).

Clauson also cites the two additional nominal forms and the one verbal form derived from ükek cited in Kāşgarī [13, p. 105-106] The first nominal form, ükeklig, is a hapax legomenon (i.e., it is attested only once): 'a wall which has towers $($ burūc) on it' is called ükeklig ta:m. The second form is: ükeklik kull $x a$ şaba u'iddat li-yuttaxad minhā 'l-șundūq 'any piece of wood prepared for making it into a box'. The verbal form ükekle:- occurs as: ol ta:mı ğ ükekle:di: 'he placed towers (wada'a...burūc) on the city wall'; also used for making boxes (sanādīq) of anything ${ }^{11}$.

\footnotetext{
${ }^{9}$ Citing it as Kaş I 78, referring to the Atalay translation (see above).

${ }^{10}$ Clauson cites Rabğuzi following [44, i, p. 1193]. See also [2, i, p. 134 (text) and 678 (glossary)].

${ }^{11}$ Clauson cites these as Kaş I 153 and Kaş I 307, referring to the Atalay translation (see above).
} 


\subsection{A Turkic Etymology: Modern Turkic Languages}

With respect to modern languages, as Clauson notes, the word survives in Tuvan and Kyrgyz. It is attested in Tuvan [56, p. 443] as:

ügek 1) 'konura'; it ügèė 'konura dlya sobaki'; 2) 'xlev (dlya molodnyaka)'; bızaa ügėė 'telyatnik'; 3) 'naves, ukrytiye na povoske (ot zhary, vetra, snega); 4) budka; tannıl ügėė 'storozhevaya budka'; 5) 'kabina'; ujudukçu ügėė 'kabina letchika'; $s r$. kabina.

In other words, the first meaning of ügek is 'hovel', with it ügèe meaning 'kennel for a dog'. The second meaning is 'shed (for a young animal)', with brzaa ügèè meaning 'veal shed'. The third meaning is 'shelter, awning (from heat, wind, snow)'. The fourth meaning is 'box, cabin', with the tannul ügèe meaning 'watch box, sentry box'. Finally the fifth meaning is 'booth', with modern term ujudukçu ügèè meaning 'crew cabin, cockpit'.

The word is also attested in Kyrgyz (Kırğ1z) [64, p. 820] as ükök 'sunduchok dlya khraneniya s"estnykh pripasov' ['a small box for storing food supplies']. Given the fact that the precise word we are looking for is to be found in Turkic, I do not see any need to try to explain it through other derivations.

\subsection{Additional Notes on the Turkic Etymology}

To Clauson's citations we may add that $\ddot{u} k a ̈ k$ also occurs with the meaning 'tower' (corresponding to Arabic burc and Persian $k \bar{o} s ̧ k$ ) in the $12^{\text {th }}-$ early $13^{\text {th }}$ century interlinear Qur'ān translation studied by Eckmann [15, p. 312]:

\section{yätär sizlärkä ölüm, näçämä bolsa sizlär ädiz yüksäk ükäklär içindä} death will overtake you though you should be in high-raised towers

The form of the name for what is today Uvek which is given by Marco Polo (Ucaca) and the forms in Arabic script (ukak, etc.) are not conclusive with regard to whether the name was pronounced originally as a back-vowel or a front-vowel word. The modern name Uvek is clearly a Russianized form no longer reflecting Turkic or Mongolian vowel harmony, but it does suggest that the name was originally a front-vowel word. Therefore Uvek must have had a front vowel in the first syllable before it was lost in Russian, in which case the earlier form would have been * üvek $\ddot{u} v \ddot{a} k^{12}$.

The form given by Marco Polo (Ucaca) and the forms in Arabic script (e.g., Ukak in Ibn Batțutta) also suggest that the name originally had an intervocalic $-k-$. The change $k>g>v(w)$ and $q>\breve{g}>v(w)$ is a regular feature of Kipchak Turkic dialects and also occurs in Oğuz Turkic dialects, for example (cited following Clauson):

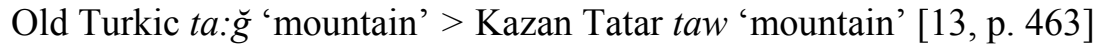
Old Turkic kögürçgün 'pigeon, dove' > Kazan Tatar kügärçen [i.e., kügärç̌̌n], Turkish güvercin 'pigeon, dove' [13, p. 713]

\footnotetext{
${ }^{12}$ For a discussion of the Russian form, including the hydronym Uvesha, see: [35].
} 


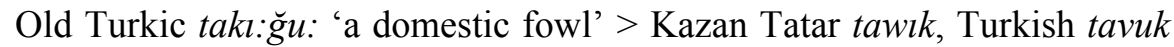
'chicken' [13, p. 468]

Based upon the considerations state above, it is easy to propose that the name developed as follows:

$$
\text { ükek } \sim \ddot{u} k \ddot{a} k>\ddot{u} g e k \sim \ddot{u} g \ddot{a} k>* \ddot{u} v e k \sim \ddot{u} v a ̈ k>\text { uvek }
$$

To complicate matters further (and for the sake of completeness), we need to remember that the vowels in languages of the Middle Volga region such as Kazan Tatar experienced a vowel shift including:

$$
*_{o}>u, \ddot{o}>\ddot{u}(\text { Kazan Tatar *on > un '10'; *böl- > bül- 'to divide'). }
$$

For this reason one could consider the possibility that the original name began not in $\ddot{u}$-, but in an earlier $* \ddot{o}$-, so $* \ddot{o k e k} \sim \ddot{o} k \ddot{a} k$. The one caution in this regard is that we do not have a precise date for the "Volga vowel shift". Since the mid-13" century is probably too early for such a shift in Turkic languages in the Middle Volga region, it would be best to consider rather forms in $\ddot{u}$ - before resorting to forms in $\ddot{o}$-. This is also suggested by the modern forms in Tuvan and Kyrgyz.

Finally, there is a long list of monosyllabic and bisyllabic roots in Old Turkic from which one could potentially seek a different source for deriving this name as well. ${ }^{13}$ While this is theoretically possible, as we have already seen above, there are multiple ways in which the meaning of this word is highly appropriate as an etymology for the modern name Uvek. For this reason there is no need to resort to other possible etymologies beyond the form found in Kaşğari.

\subsection{A Mongolian Etymology?}

As Menges has noted, the same word exists in quite a number of Mongolian languages. In addition to the earlier sources he cites, I will note that this same word is attested in Classical Mongolian as ükeg üküg 'chest, case, box, cupboard' [27, p. 1002-1003]. The word is also attested the on-line Bolor Khalkha Mongolian dictionary as üxég 'case, box, trunk, chest', search under үхэг in: [60]. The large on-line explanatory dictionary for Khalkha Mongolian gives both the forms $\ddot{u} x \dot{e} g$ and $\ddot{u} x \dot{e} g l e \dot{x}$ (the latter form could also be a Turkic loanword in Mongolian), search under үхэг and үхэглэх in: [61]. The word is also to be found with the same range of meanings in Buryat [12, p. 521]:

üxėg 1) nizen'kiy shkaf dlya skladyvaniya veshchey; shkafchik v vide tumbochki; 2) podstavka dlya sunduka; 3) yashchik.

The same is the case for Kalmyk, except it is considered an archaic form [40, p. 549], with the. abbreviation ust. standing for ustarevshee slovo 'archaic form'.

${ }^{13}$ For this reason there is no reason to review all other possibilities for our purposes here. For an exhaustive list of front-vowel nominal roots see: [13, p. 98-99, 100-101, and 105]; for back-vowel nominal roots (which we should not be considering!) see [13, p. 75-76, 78-79, and 82-83]. 


\section{üküg I ust. posudnyy shkaf; lar'; ükügüt ümkä mxi zagadka v shkafu tuxloye myaso (ul'trg stel'ka) \\ üküg II ust. sarkofag}

Finally the word is also attested in Ordos [36, p. 754] (following Mostaert's transcription):

$\boldsymbol{u}^{\boldsymbol{c} \boldsymbol{x}} \boldsymbol{x} \boldsymbol{e k l e - ~ ' m e t t e r ~ d a n s ~ u n e ~ c a i s s e ~ p o u r ~ c o n s e r v e r ~ l e s ~ v i c t u a i l l e s . ' ~ [ ' t o ~ p u t ~ i n ~}$ a chest to preserve food' - U.S.]

$\boldsymbol{u}^{c k} \boldsymbol{x} \boldsymbol{e k}$ 'caisse pour conserver les victuailles.' ['a chest for preserving food'-U.S.] [Mongolian ükeg]

The fact that the word $\ddot{u} k e k$ and forms derived from it occurs in both Old Turkic and Classical Mongolian makes it difficult to rule out either language as the original language. The fact that the word survives in a rather large number of Mongolian languages but in only two modern Turkic languages may suggest that it was borrowed into Old Turkic and into a small number of modern Turkic languages, or it may simply be a sign that the traditional culture of the nomads survived longer among the speakers of various Mongolian languages. If we consider the denominal verb ükekle-, it appears that it is more likely to be of Turkic origin than a verbal form native to Mongolian, since according to Poppe, Classical Mongolian would not employ the the suffix -la/-le to create a verb from ükek [43, p. 65]. The suffix -liğ (as in Khalkha üxéglèx, see above) would not necessarily form ükeklik in Mongolian, whereas it is more easily seen as a ubiquitous formation in Turkic ${ }^{14}$. Of course, it is also possible that the original root was borrowed into both Turkic and Mongolian from a third language before the $11^{\text {th }}$ century.

\section{REFERENCES}

1. Abū 1-Fidā. Géographie d'Aboulféda, ii/1. J.T. Reinaud (trans.). Paris, 1848. (In French)

2. Al-Rabghūzī. The Stories of the Prophets: Qiṣaș al-anbiyā'. An Eastern Turkish Version, i-ii. H.E. Boeschoten et al. (eds., trans.). Leiden, Brill, 1995.

3. Anonim Iskendera, in: V.G. Tizengauzen, Sbornik materialov otnosyashchikhsya $k$ istorii Zolotoy ordy, ii: Izvlecheniya iz persidskikh sochineniy [Collection of Materials Related to the Golden Horde's History. Vol. II: Excerpts from the Persian Writings]. A.A. Romaskevich and S.L. Volinyy (eds.). Moscow-Leningrad, 1941, pp. 126-138 and 232-242. (In Persian, Russian)

4. Arat R.R. Kutadgu bilig, i: Metin. Istanbul, 1947. (In Turkish)

5. Bartol'd V.V. Bolgary [The Bolgars]. Sochineniya, v [Writings, Vol. V]. Moscow, 1968. (In Russian)

6. Bartol'd V.V. Dvenadtsat' lektsiy po istorii turetskikh narodov Sredney Azii [Twelve Lectures on the History of the Turkish Peoples of Central Asia]. Sochineniya, v [Writings, Vol. V]. Moscow, 1968. (In Russian)

7. Bartol'd V.V. Mesto prikaspiyskikh oblastey v istorii musulmanskogo mira [The Role of the Caspian Regions in the History of the Muslim World]. Sochineniya, ii/1 [Writings, Vol. II/1]. Moscow, 1963. (In Russian)

${ }^{14}$ See [46, p. 42] for the example: çeçeg + -lĭg > çeçeglĭg or çeçerliğ. 
8. Bartol'd V.V. Novyy trud o polovtsakh [A New Work on the Polovtsians]. Sochineniya, v [Writings, Vol. V]. Moscow, 1968. (In Russian)

9. Blum J. Lord and Peasant in Russia from the Ninth to the Nineteenth Century. Princeton, 1961.

10. Bratashova S.A. Ranniy Saratov: Na perekrestke putey i epokh [Early Saratov: At the Crossing of Ways and Epochs]. Saratov, 2015. (In Russian)

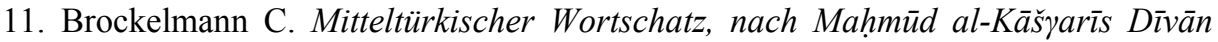
Luүāt at-Turk. Bibliotheca Orientalis Hungarica 1. Budapest, 1928. (In German)

12. Cheremisov K.M. Buryat-mongol'sko-russkiy slovar' [Buryat-Mongolian-Russian Dictionary]. Moscow, 1951. (In Russian)

13. Clauson G. An Etymological Dictionary of Pre-Thirteenth Century Turkish. Oxford, 1972.

14. Drevnetyurksiy slovar' [Old Turkic Dictionary]. V.M. Nadelyaev et al. (eds.). Leningrad, 1969. (In Russian)

15. Eckmann J. Middle Turkic Glosses of the Rylands Interlinear Koran Translation. Bibliotheca Orientalis Hungarica 21. Budapest, 1976.

16. Fasmer M. Etimologicheskiy slovar' russkogo yazyka, vol. i-iv [Etymological Dictionary of the Russian Language. Vol. I-IV]. Moscow, 1986-1987. (In Russian)

17. Fedorov-Davydov G.A. Städte der Goldenen Horde an der unteren Wolga. Materialien zur Allgemeinen und Vergleichenden Archäologie 11. Münich, 1984. (In German)

18. Fedorov-Davydov G.A. Zolotoordynskie goroda Povolzh'ya [Golden Horde's Cities of the Volga Region]. Moskva, 1994. (In Russian)

19. Fyodorov-Davydov G.A. The Culture of the Golden Horde Cities. British Archaeological Reports, International Series 198. Oxford, 1984.

20. Gaffārī. Nusax-i cahān-ārāa, in: V.G. Tizengauzen, Sbornik materialov otnosyashchikhsya $k$ istorii Zolotoy ordy, ii: Izvlecheniya iz persidskikh sochineniy [Collection of Materials Related to the Golden Horde's History. Vol. II: Excerpts from the Persian Writings]. A.A. Romaskevich and S.L. Volinyy (eds.). Moscow-Leningrad, 1941, pp. 210212 and 269-271. (In Persian, Russian)

21. Ibn al-Muhannā. Kitāb Hilyat al-insān wa-halabat al-lisān, yahut, İbni Mühennâ lûgati. Kilisli Muallim Rifat (ed.). Istanbul, 1922. (In Arabic)

22. Ibn Batțutta. The Travels of Ibn Bațtutta, A. D. 1325-1354, i-iii. H.A.R. Gibb (trans.). Works Issued by the Hakluyt Society, II, 110, 117, and 141. Cambridge, 19581971.

23. Kirakos of Ganjak. History of the Armenians. R. Bedrosian (trans.). New York, Sources of the Armenian Tradition, 1986.

24. Kirakos of Ganjak. Istoriia Armenii [The History of Armenia]. L.A. Khanlarian (trans.). Pamyatniki pis'mennosti Vostoka 53. Moscow, 1976. (In Russian)

25. Kramarovskiy M. Gorod i gorodskaya zhizn' v Zolotoy Orde [The City and the City Life in the Golden Horde]. Istoriya Tatar s drevneyshikh vremen v semi tomakh, iii: Ulus Dzhuchi (Zolotaya Orda). XIII-seredina XV v. [History of the Tatars from the Most Ancient Times in Seven Volumes. Vol. III: The Jochid Ulus (the Golden Horde). $13^{\text {th }}-$ mid- $15^{\text {th }}$ centuries]. Kazan, 2009, pp. 567-589. (In Russian)

26. Le Goff J. Medieval Civilization, 400-1500. J. Barrow (trans.). New York, 1989.

27. Lessing F.D. Mongolian-English Dictionary. Berkeley, 1960/Bloomington, 1980.

28. Maḥmūd al-Kāšyarī. Compendium of the Turkic Dialects (Dīwān Luүāt at-Turk). Robert Dankoff and James Kelley (ed., trans). Sources of Oriental Languages and Literatures 7. Duxbury, MA, 1982-1985.

29. Maḥmūd al-Kāşgàarī. Divanü lûgat-it-türk tercümesi, i-iv. B. Atalay (trans.). Ankara 1939-1941/1985-1986. (In Turkish)

30. Marco Polo, The Travels. Ronald Latham (trans.). New York, Penguin, 1958. 
31. Marquart J. Über das Volkstum der Komanen, in: W. Bang and J. Marquart. Osttürkische Dialektstudien. Abhandlungen der Gesellschaft der Wissenschaften zu Göttingen. Philologisch-Historische Klasse, N.F. 13:1. Berlin, 1914/Göttingen, 1970. (In German)

32. Maxmūd al-Kāshġarī. Dìvān lugiāt at-Turk. Z.-A. Auezova (trans.). Almaty, DaykPress, 2005. (In Russian)

33. Maxmut Qashqari. Türik sözdigi. Asqar Qurmashulı Egeubay (trans.). Almaty, Khant, 1997-1998. (In Kazakh)

34. Melyoranskiy P.M. Arab filolog o turetskom yazyke [The Arabic Philologist about the Turkish Language]. St. Petersburg, 1900. (In Russian)

35. Menges K.H. Uvek/Ükäk, 'Mauerturm, Bastion', Zeitschrift für Slavische Philologie 24:1 (1955), pp. 30-31. (In German)

36. Mostaert A. Dictionnaire ordos. Second Edition. New York, 1968. (In French)

37. Muniyev B.D. Kalmytsko-russkiy slovar' [Kalmyk-Russian Dictionary]. Moscow, 1977. (In Russian)

38. Națanzī. Muntaxab at-tavārīx-i Mu'īnī. J. Aubin (ed.). Tehran, 1957. (In Persian)

39. Nedashkovskii L.F. Zolotoordynskie goroda Nizhnego Povolzh'ya i ikh okruga [Golden Horde Cities of the Lower Volga Region and Their Districts]. Moscow, Vostochnaya literatura Publ., 2010. (In Russian)

40. Nedashkovskii L.F. Zolotoordynskiii gorod Ukek i ego okruga [The Golden Horde City of Ukek and Its Districts]. Moscow, Vostochnaya literatura Publ., 2000. (In Russian)

41. Nedashkovsky L.F. Ukek: The Golden Horde City and Its Periphery. An Analysis of the Written, Numismatic and Artefactual Evidence for the City of Ukek and the Jochid State on the Volga, $12^{\text {th }}$ to $15^{\text {th }}$ centuries. British Archaeological Reports S1222. Oxford, England: Archaeopress, 2004.

42. Nizām al-Dīn Shāmī. Zāfarnāma, in: V.G. Tizengauzen, Sbornik materialov otnosyashchikhsya $k$ istorii Zolotoy ordy, ii: Izvlecheniya iz persidskikh sochineniy [Collection of Materials Related to the Golden Horde's History. Vol. II: Excerpts from the Persian Writings]. A.A. Romaskevich and S.L. Volinyy (eds.). Moscow-Leningrad, 1941, pp. 104126. (In Persian, Russian)

43. Poppe N. Grammar of Written Mongolian. Wiesbaden, 1974.

44. Radloff W. Versuch eines Wörterbuches der Türk-Dialecte/Opyt slovarya tyurkskikh narechiy, i-iv. St. Petersburg, 1893. (In German, Russian)

45. Richard J. La Papauté et les missions d'orient au Moyen-Age (XIII $-X V^{e}$ siècles). Rome, 1977. (In French)

46. Schaeder H.H. Vorwort, in: J. Markwart, Wehrot und Arang. Untersuchungen zur mythischen und geschichtlichen Landeskunde von Ostiran, H.H. Schaeder (ed.). Leiden, 1938. (In German)

47. Schamiloglu U. Climate Change in Central Eurasia and the Golden Horde. Zolotoordynskoe obozrenie $=$ Golden Horde Review. 2016. Vol. 4, no. 1, pp. 6-25.

48. Schamiloglu U. The Impact of the Black Death on the Golden Horde: Politics, Economy, Society, and Civilization. Zolotoordynskoe obozrenie=Golden Horde Review. 2017. Vol. 5, no. 2, pp. 325-343.

49. Schamiloglu U. The Islamic High Culture of the Golden Horde, Proceedings of the Second International Symposium on Islamic Civilization in the Volga-Ural Region: Kazan, 24-26 June 2005, Rafik Muhammetshin, Zeynep Durukal, and Güler Doğan (eds.). Sources and Studies on the History of Islamic Civilization. Istanbul, Research Centre for Islamic History, Art and Culture, 2008, pp. 19-39.

50. Schamiloglu U. Torgovlya Ulusa Dzhuchi so stranami Sredizemnemor'ya [The Trade of the Jochid Ulus with the Mediterranean Countries]. Istoriya Tatar s drevneyshikh vremen v semi tomakh, iii: Ulus Dzhuchi (Zolotaya Orda). XIII-seredina XV v. [History of the Tatars from the Most Ancient Times in Seven Volumes. Vol. III: The Jochid Ulus (the Golden Horde). $13^{\text {th }}-$ mid-15 ${ }^{\text {th }}$ centuries]. Kazan, 2009, pp. 287-294. (In Russian) 
51. Schamiloglu U. Vysokaya islamskaya kul'tura Zolotoy Ordy [The High Islamic Culture of the Golden Horde]. Istoriya Tatar s drevneyshikh vremen v semi tomakh, iii: Ulus Dzhuchi (Zolotaya Orda). XIII-seredina XV v. [History of the Tatars from the Most Ancient Times in Seven Volumes. Vol. III: The Jochid Ulus (the Golden Horde). $13^{\text {th }}-$ mid-15 $5^{\text {th }}$ centuries]. Kazan, 2009, pp. 589-598. (In Russian)

52. Schamiloglu U. The Golden Horde: Economy, Society, and Civilization in Western Eurasia, Thirteenth-Fourteenth Centuries. Madison, Turko-Tatar Press, forthcoming.

53. Sharaf al-Dīn Yazdī. Zāfarnāma, in: V.G. Tizengauzen, Sbornik materialov otnosyashchikhsya $k$ istorii Zolotoy ordy, ii: Izvlecheniya iz persidskikh sochineniy [Collection of Materials Related to the Golden Horde's History. Vol. II: Excerpts from the Persian Writings]. A.A. Romaskevich and S.L. Volinyy (eds.). Moscow-Leningrad, 1941, pp. 144190 and 248-250. (In Persian, Russian)

54. Siberian Ice Maiden. Available at: en.wikipedia.org/wiki/Siberian_Ice_Maiden. Accessed: January 5, 2016.

55. Spuler B. Die Goldene Horde. Die Mongolen in Russland, 1223-1502. Second Edition. Wiesbaden, 1965. (In German)

56. Tenishev E.R. Tuvinsko-russkiy slovar' [Tuvinian-Russian Dictionary]. Moscow, 1968. (In Russian)

57. 'Umarī. Das mongolische Weltreich. Al-'Umarī's Darstellung der mongolischen Reiche in seinem Werk Masālik al-absār fì mamālik al-amșār. K. Lech (ed., trans.). Asiatische Forschungen 22. Wiesbaden, 1968. (In German)

58. Vașșāf. Târīx-i Vașșāf, in: V.G. Tizengauzen, Sbornik materialov otnosyashchikhsya $k$ istorii Zolotoy ordy, ii: Izvlecheniya iz persidskikh sochineniy [Collection of Materials Related to the Golden Horde's History. Vol. II: Excerpts from the Persian Writings]. A.A. Romaskevich and S.L. Volinyy (eds.). Moscow-Leningrad, 1941, pp. 8089. (In Russian)

59. William of Rubruck. Mission to Asia. A Nun of Stanbrook Abbey (trans.), C. Dawson (ed.). London, 1955/Toronto, 1980.

60. Available at: www.bolor-toli.com. Accessed: December 23, 2015.

61. Available at: www.mongoltoli.mn. Accessed: December 23, 2015.

62. Yegorov V.L. Istoricheskaya geografiya Zolotoy Ordy v XIII-XIV vv. [The Historical Geography of the Golden Horde in the $13^{\text {th }}-14^{\text {th }}$ centuries]. Moscow, 1985. (In Russian)

63. Yanina A. Obshchiy obzor kollektsii dzhuchidskikh monet iz raskopok i sborov Kuybyshevskoy ekspeditsii v Bolgarakh (1946-1958 gg.) [General Overview of the Collection of Jochid Coins from Excavations and Collections of the Kuibyshev Expedition in Bolgars (1946-1958)]. Trudy Kuybyshevskoy ekspeditsii, iv [Proceedings of the Kuibyshev Expedition, Vol. IV]. Materialy i issledovaniya po arkheologii SSSR 111. Moscow, 1962, pp. 153-178. (In Russian)

64. Yudakhin K.K. Kirgizsko-russkiy slovar' [Kyrgyz-Russian Dictionary]. Moscow, 1965. (In Russian)

About the author: Uli Schamiloglu - Ph.D. (History), Professor, Nazarbayev University (Astana 010000, Kazakhstan); Department of German, Nordic, and Slavic, University of Wisconsin-Madison, ORCID: http://orcid.org/0000-0003-0658-1267 (1220 Linden Drive, Madison, WI 53706, USA).E-mail: uschamil@wisc.edu 


\section{APPENDIX}

1. Ükek Daba (Khangay Mountains, Mongolia) located at 47 degrees N latitude and $100.2\left(100^{\circ} 12^{\prime}\right)$ degrees E longitude

[Source: Google Earth. Accessed: December 3, 2017]

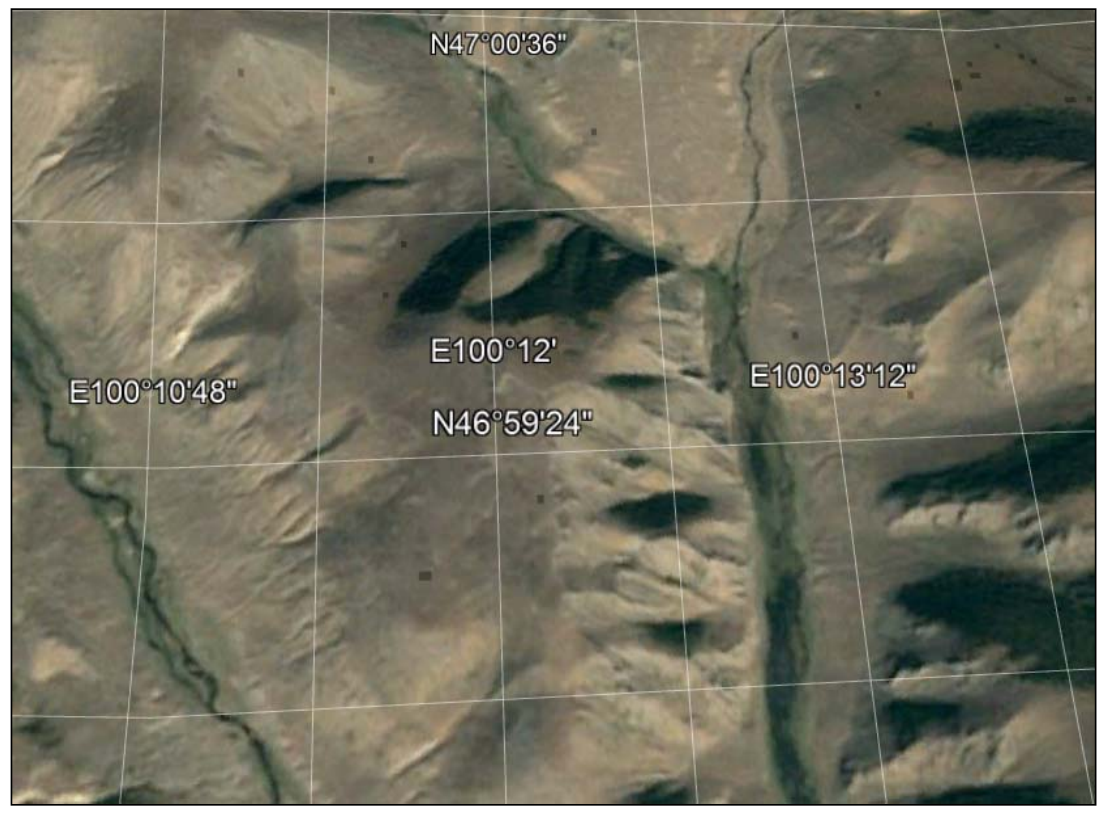

2. Uvek (Saratov, Russia)

[Source: http://delovoysaratov.ru/news/region-news/vyishel-v-svet-film-ukek0211/. Accessed: January 5, 2016]

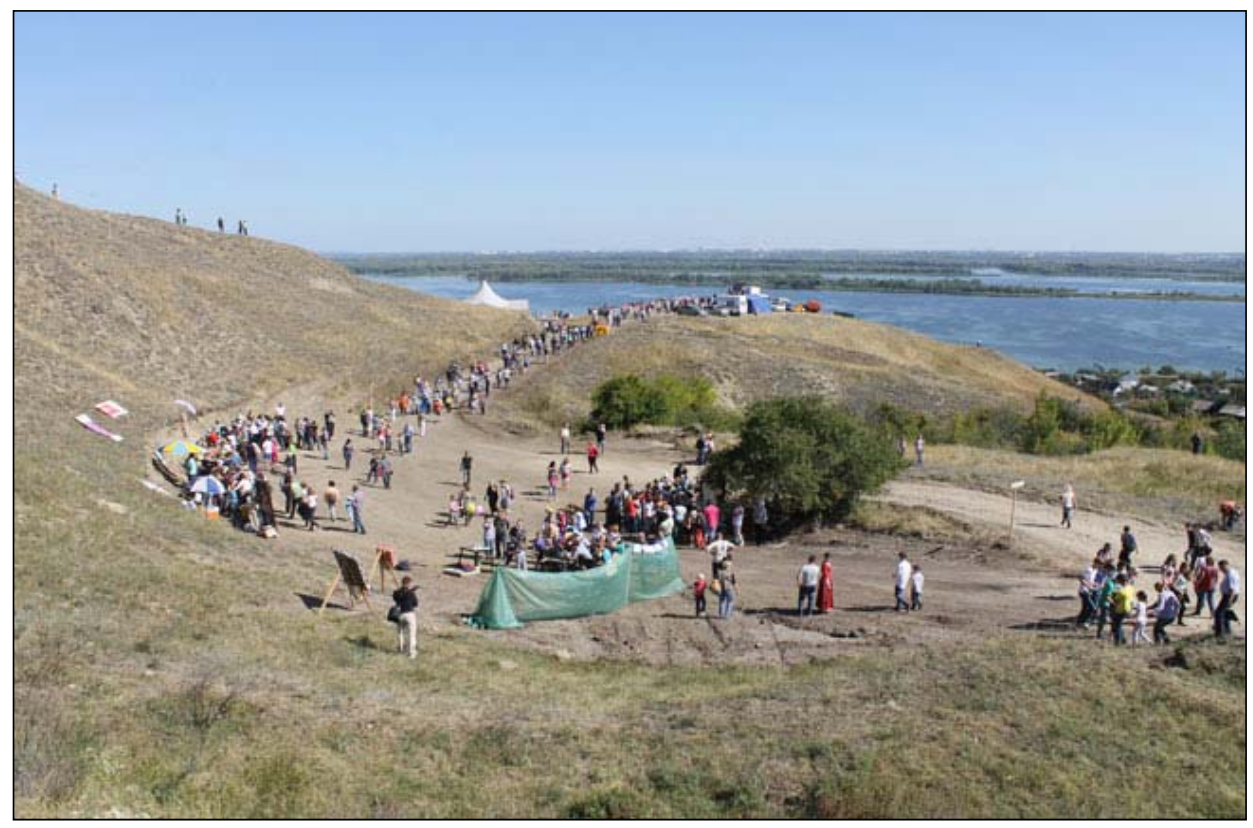


3. Topographic Map of Uvek (Saratov, Russia)

[Source: http://en-us.topographic-map.com/places/Saratov-3673179/.

Accessed: January 5, 2016]

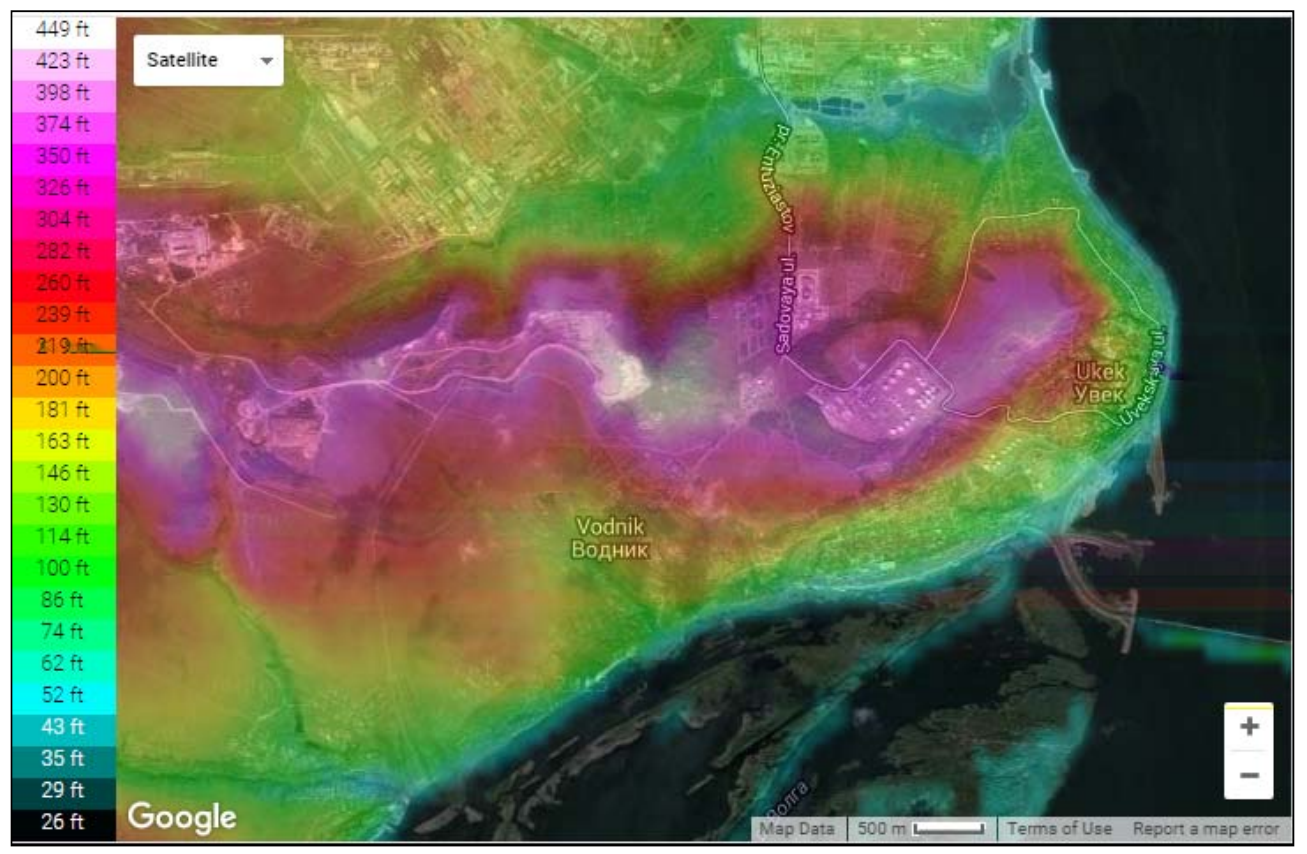

4. Ükek Pass, Kyrgyzstan (Photo by Jürgen Grösel, June 2012)

[Source: http://www.panoramio.com/photo/75661089.

Accessed: January 5, 2016]

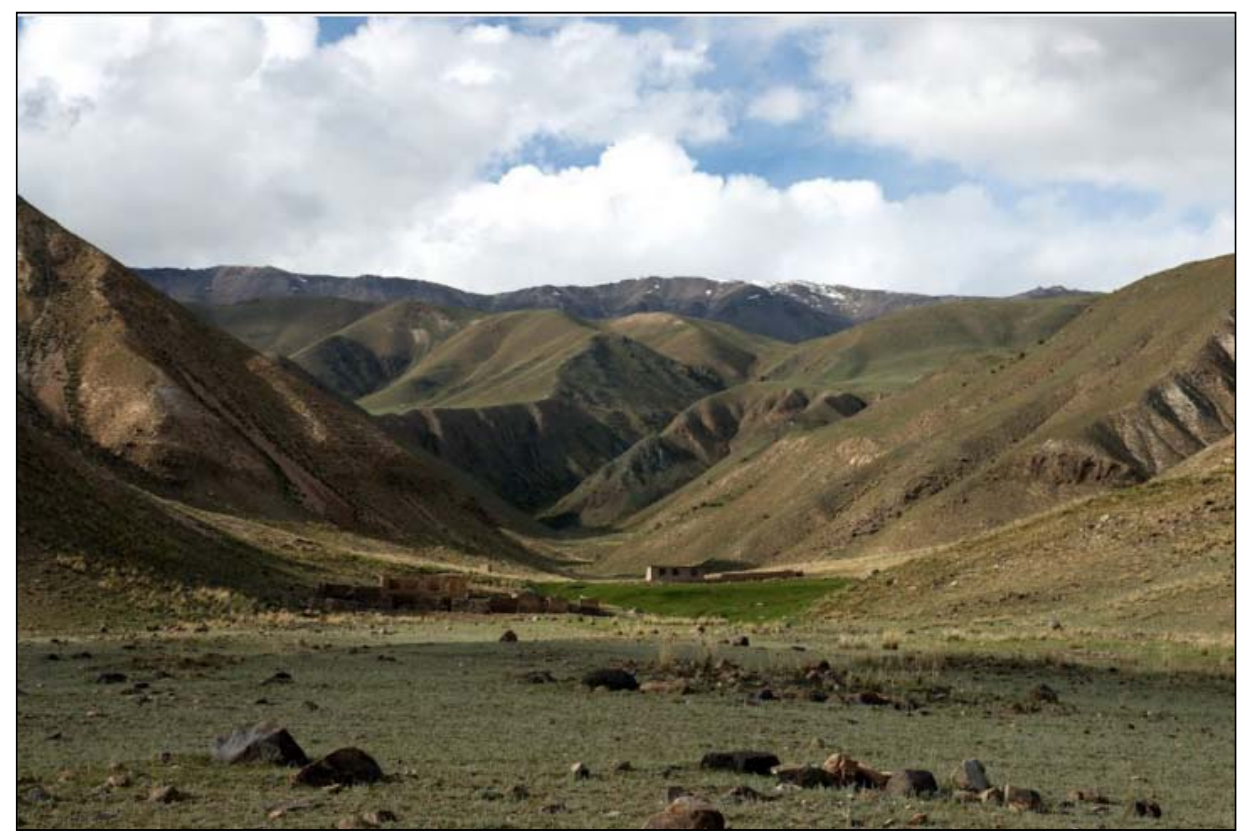


5. Köl Ükök Lake, Kyrgyzstan

[Source:

http://www.wikiloc. com/wikiloc/imgSer ver.do?id=734926.

Accessed:

January 5, 2016]

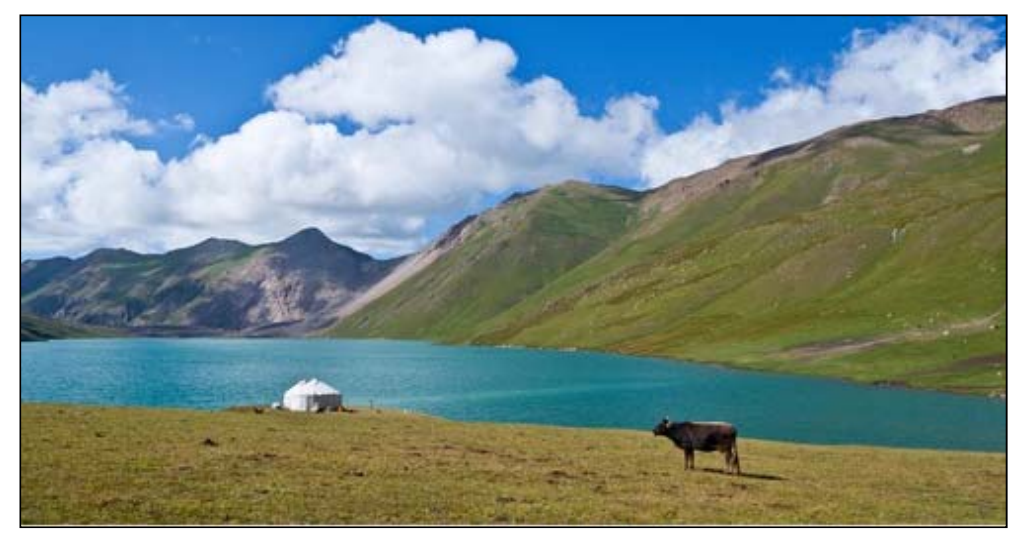

6. Ükök Suusu River, Kyrgyzstan

[Source: https://www.flickr. com/photos/62516383 @)N04/8491680629 /in/photostream/.

Accessed: January 5, 2016]

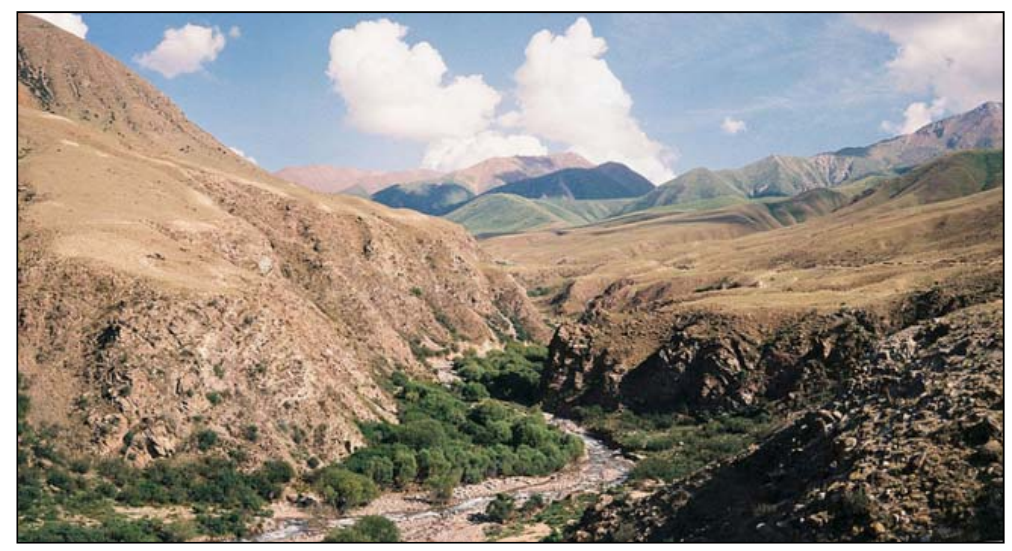

7. Ükök Plateau, Kosh-Agachsky District, Altay Republic, Russian Federation (Photo by Richard Lozin, October 2010)

[Source: http://www.panora mio.com/photo 142979279 .

Accessed: January 5, 2016]

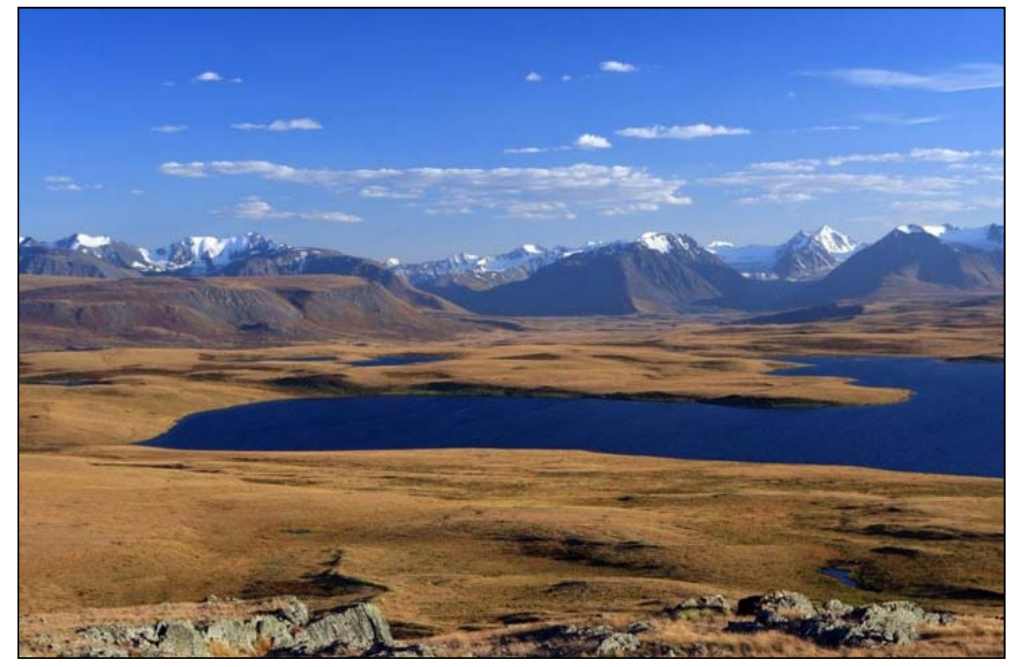




\title{
ПОДЬЕМ ГОРОДСКИХ ЦЕНТРОВ В ЗОЛОТОЙ ОРДЕ И ГОРОД УКЕК
}

\author{
Юлай Шамильоглу ${ }^{1,2}$ \\ ${ }^{1}$ Назарбаев Университет \\ Астана, Казахстан \\ ${ }^{2}$ Висконсинский университет в Мадисоне \\ Madison, USA \\ uschamil@wisc.edu
}

Цель и материалы исследования: в данной статье рассматривается подъем городов на территории Золотой Орды. В ней контекстуализируется информация, встречающаяся у таких средневековых путешественников, как Марко Поло и Гийом де Рубрук, для изучения перехода кочевнической экономики к оседлой экономике. Такие арабоязычные авторы, как Абу-ль-Фида, позволяют обозреть местонахождение крупных городских центров, в то время как Ибн Баттута позволяет глубже понять внутреннее устройство городов. Хотя Укек появился как городской центр, расположенный на северной оконечности маршрута ежегодных кочевнических миграций и на полпути из столичного города Сарая на юге и из города Булгара на севере, в данной статье утверждается, что, вполне возможно, он приобрел позже важность как центр производства зерна вследствие климатического изменения. В статье также делается попытка понять происхождение и значение названия Укек, представляя в отношении его этимологии подробное рассмотрение средневековых и современных сведений.

Результаты и новизна исследования: в статье выдвигается предположение, что название Укека в действительности отображает информацию о геологической формации места, где он был построен. В то время, как большинство исследователей считали, что изначально оно означало «ящик», под которым подразумевались укрепления на городской стене, автор утверждает, что это название скорее указывает на похожие на ящик полые очертания местности, предоставлявшие как убежище, так и расположение на возвышенности, и которые были видны путешественникам и представлялись в форме, легко узнаваемой для путешественников, прибывавших с расстояния в тысячи километров с юго-востока, где находились несколько подобных же местностей с той же формой и тем же названием.

Ключевые слова: Укек, номадизм, стоянки, прото-города, городские центры, Сарай, геологическая особенность, производство зерна, тюркская этимология, монгольская этимология

Для цитирования: Schamiloglu U. The Rise of Urban Centers in the Golden Horde and the City of Ükek // Золотоордынское обозрение. 2018. Т. 6, № 1. C. 18-40. DOI: 10.22378/2313-6197.2018-6-1.18-40

Сведения об авторе: Юлай Шамильоглу - Ph.D. (история), профессор, Назарбаев Университет (Астана 010000, Казахстан); департамент немецкого, скандинавских и славянских языков, Висконсинский университет в Мадисоне, ORCID: http://orcid.org/0000-0003-0658-1267 (1220 Linden Drive, Madison, WI 53706, USA). E-mail: uschamil@wisc.edu 